\title{
KURIKULUM BERBASIS AL-QURAN (KBQ) PADA ANAK USIA DINI
}

\author{
Oleh: Nur Komariah
}

\begin{abstract}
Abstrak
Kurikulum Bebasis al-Qur'an (KBQ) adalah sebuah kurikulum yang tidak memisahkan ilmu pengetahuan umum dan ilmu pengetahuan Agama. KBQ adalah sebuah kurikulum yang menanamkan nilainilai Islam yang terkandung dalam al-Qur'an dan al-Hadis ke dalam seluruh kegiatan pendidikan. Penerapan KBQ pada anak usia dini dimaksudkan untuk memberikan pengetahuan Agama lebih dini sehingga anak didik tidak hanya memiliki keterampilan, ahlaq yang terpuji namun anak didik juga memiliki ilmu pengetahuan agama sejak dini, memiliki keyakinan yang kokoh akan adanya Allah sebagai Robbnya sehingga hal ini menjadi modal yang paling berharga dalam meniti kehidupan selanjutnya.
\end{abstract}

Kata Kunci: Kurikulum Berbasis Al-Qur'an, Anak Usia Dini

\section{A. Pendahuluan}

Kurikulum merupakan alat untuk mencapai tujuan pendidikan. Karenanya kurikulum memiliki posisi yang sangat penting dalam dunia pendidikan. Mengingat begitu penting kedudukan kurikulum dalam dunia pendidikan, maka para praktisi pendidikan terus melakukan upaya perbaikan secara berkesinambungan dan yang paling teranyar adalah kurikulum 2013 namun pada implementasinya masih saja dijumpai kendalakendala hingga pada ahirnya pemerintah pusat memutuskan untuk kembali mengimplementasikan Kurikulum Tingkat Satuan Penddikan (KTSP). 


\section{JURNAL AL-AFKAR}

Vol. III, No. 1, April 2015

Berdasarkan pengertian tradisional kurikulum adalah sejumlah mata pelajaran yang harus ditempuh anak didik guna mendapatkan suatu ijazah atau kelulusan. Berdasarkan pengertian ini dapat difahami bahwa yang dimaksud dengan kurikulum adalah mata pelajaran. Dengan menguasai sejumlah mata pelajaran yang ditetapkan oleh pihak sekolah atau yayasan maka siswa telah lulus dan berhak mendapatkan ijazah. Adapun pengertian kurikulum secara modern kurikulum adalah seperangkat rencana pembelajaran yang tediri dari tujuan pembelajaran, isi atau matei pembelajaran, metode pembelajaran, media pembelajaran, strategi pembelajaran, serta alat evaluasi pembelajaran. Berdasarkan pengertian ini pengertian kurikulum telah mengalami perkembangan yang sebelumnya hanya sebatas penguasaan materi namun pada pengertian kurikulum modern kuriulum tidak hanya sebatas penguasaan materi pembelajaran namun siswa ditutuntut untuk mampu memparaktekkan materi pembelajaran kedalam dunia nyata tidak hanya sebatas teori atau hafalan.

Kurikulum berbasis Alqur'an (KBQ) adalah inovasi kurikulum yang pertama kali dikenalkan oleh Prof. Dr. E. Mulyasa, M.Pd. pada sebuah pertemuan di Institut Agama Islam Negeri Sunan Gunung Djati (IAIN SGD) Bandung sekitar awal maret 2003. Menurut Mulyasa implementasi kurikulum berbasis al-Quran menjadi sangat penting mengingat situasi dan kondisi Negara yang semakin hari semakin memperihatinkan kondisi ahlaqnya. Dengan di implementasikannya KBQ pada anak usia dini diharapkan akan melahirkan generasi-generasi yang kuat dan kokoh keimananya, siap mengahadapi situasi dan kondisi apapun tidak mudah goyah dengan hanya sekedar kenikmatan sesaat sebatas kenikmatan dunia. Dengan di implementasikannya KBQ 
diharapkan generasi anak bangsa mampu menjadikan Al-Qur'an sebagai pegangan hidupnya serta meneladani ahlaq Rasulullah saw.

Al-Qur'an sebagaimana yang kita fahami bersama bahwa Al-quran adalah kalamullah yang diwahyukan kepada nabi Muhammad SAW. Al-Qur'an adalah sumber autentik yang tidak diragukan kebenarannya yang didalamnya mengajarkan tentang Tauhid, Ibadah, Muamalah, Nujum, Sejarah, Bahasa dan Sastra dan lain-lain. Dengan merujuk kepada Al-Qur'an sebagai pondasi dasar keilmuan maka akan menanmkan kepada anak didik kita bahwa al-Quran adalah sumber ilmu disamping itu dengan mengimplemntasi KBQ diharapkan anak didik akan menjadikan Al-Qur'an sebagai rujuakan pertama dalam menggali informasi.

Implementasi KBQ menjadi sangat penting jika kita merasa perlu menciptakan sebuah generasi yang kuat yang tidak mudah tergiur dengan kenikmatan sesaat yang pada dasarnya itu hanyalah tipuan belaka, karena sesungguhnya kehidupan yang hakiki adalah kehidupan di aherat karena itulah pengenalan akan tujuan hidupnya yakni Robnya perlu ditanamkan sejak dini.

Pendidikan Anak Usia Dini (PAUD) adalah sebuah wahana pendidikan yang diperuntukkan bagi anak usia 0-6 tahun yang dilakukan melalui pemberian rangsangan pendidikan untuk membantu pertumbuhan dan perkembangan jasmani dan ruhani anak didik agar anak didik siap untuk memasuki pendidikan yang lebih tinggi.

PAUD adalah sebuah lingkungan yang dibentuk sedemikian rupa guna membentuk karakter anak didik yang di inginkan mengingat lingkungan memiliki peranan yang penting dalam membentuk karakter anak didik. Mengingat begitu penting 


\section{JURNAL AL-AFKAR}

Vol. III, No. 1, April 2015

peranan lingkungan maka sebuah lembaga pendidikan yang berkomimen untuk mencerasakan anak didik bangsa perlu untuk merencanakan, mengimplementasikan dan menevaluasi kiranya bagaimana kendaraan atau alat pacu guna menempuh atau mencapai sebuah tujuan pendidikan.

\section{B. Pembahasan}

KBQ PAUD adalah sebuah kurikulum yang didesain sedemikian rupa guna membentuk karakter anak didik yang sesuai dengan ajaran al-Qur'an, yang bertaqwa pada Robbnya, yang cerdas dan memiliki keterampilan. Siswa yang berkarakter namun beriman kepada Allah SWT. Sehingga kedepannya menciptakan generasi penerus bangsa yang tidak hanya trampil namun memiliki kepribadian yang matang yang siap dalam menghadapi setiap tantangan dan perubahan zaman tanpa menggadaikan keimanan dengan harta, keuasaan, tahta maupun wanita, karena secara fitrahnya manusia telah memiliki dasar keimanan dalam hatinya namun lingkunganlah yang mempengaruhi keimananya.

\section{a. Fitrah Manusia}

Manusia adalah Mahluk Allah yang paling mulia dan paling sempurna dibandingkan dengan mahluk yang lain. Secara struktur manusia terdiri dari unsur jasmani (fisiologis) dan ruhani (psikologis,) dari kedua unsure tersebut Allah telah memberikan kemampuan dasar yang mampu membedakan mana yang baik dan mana yang buruk. Kemampuan dasar inilah yang kemudian dinamakan fitrah.

Fitrah berasal dari kata fatara yang artinya mencipta biasanya digunakan dalam al-qur'an untuk menunjukkan pengertian 
sesuatu yang sebelumnya belum ada dan masih merupakan pola dasar yang perlu penyempurnaan. ${ }^{1}$ Kata fitrah disebutkan dalam al qur'an surat Ar-Rum Ayat 30 sebagai berikut :

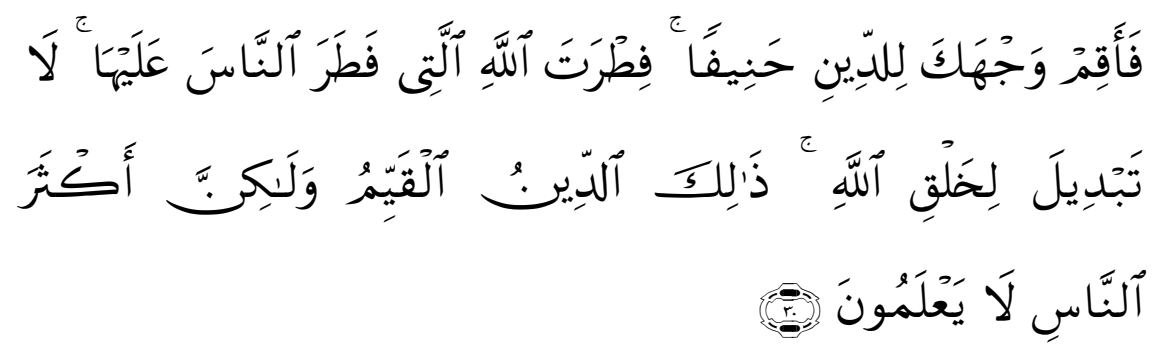

Artinya: "Maka hadapkanlah wajahmu kepada agama dengan seluruslurusnya (sesuai dengan kecenderungan aslinya) itulah fitrah Allah, yang menciptakan manusia atas fitrah. Itulah agama yang lurus. Namun kebanyakan orang tidak mengetahuinya" (Q.S. al-Rum:30)

Di samping itu terdapat beberapa sabda Nabi SAW yang popupler antara lain sebagai berikut;

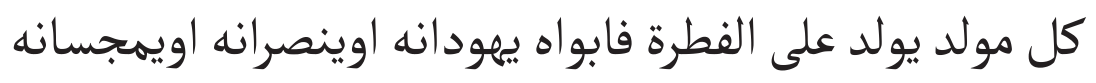

Artinya: "Tiap-tiap anak dilahirkan di atas fitrah maka ibu-bapaknyalah yang mendidiknya menjadi orang yang beragama Yahudi, Nasrani, atau Majusi" (al-Hadis)

Berdasarkan al-Quran dan Al-Hadis dapat di ambil kesimpulan bahwa yang dimaksud dengan fitrah adalah kemampuan dasar yang dimiliki setiap manusia untuk berkembang baik itu berkembang dalam segi keimanan atau keyakinan maupun berkembang dalam segi keterampilan.

Untuk mengembangkan kemampuan dasar atau pembawaan yang dibawa sejak lahir agar mampu berkembang secara optimal

1 Achmadi, 2005, Ideologi Pendidikan Islam, (Yogyakarta: Pustaka Pelajar, 2007), hal. 41. 
pelu diciptakan sebuah lingkungan yang mampu membawa manusia menuju jalan yang dibenarkan agama Allah. Karena tujuan dari pada penciptaan manusia adalah pengabdian atau penghambaan diri kepada Allah swt. Dan hal ini tidaklah hanya semata meyakini saja akan tetapi perlu diaplikasikan kedalam perilaku sehari-hari seperti yang tertuang di dalam rukun iman dan rukun islam. Oleh karena itu perlu penciptaan lingkungan yang mendukung manusia untuk mengoptimalkan potensi yang sudah ada dibawa sejak lahir melalui pendidikan.

PAUD adalah sebuah wadah yang memberikan pendidikan kepada anak-anak dari usia 0-6 tahun yang bertujuan memberikan kesiapan jasmani maupun ruhaninya agar lebih siap memasuki tingkat sekolah yang lebih tinggi. Secara fitrah anak sudah memiliki petensi yang dibawa sejak lahir dan secara otomatis akan tumbuh dan berkembang namun kearah mana anak tersebut akan tumbuh dan berkembang sesuai dengan lingkungan dimana anak tumbuh.

Mengingat begitu penting sebuah lingkungan dalam pembentukan karakter anak maka kurikulum sebagai alat pacu menuju tujuan perlu didesain dengn apik agar tujuan pendidikan yang islam benar-benar tercapai. Sebuah tujuan pendidikan yang tidak hanya memandang dunia sebagai tujuan, kepentingan pribadi sebagai tujuan namun tujuan kehidupan dunia dengan tidak menyampingkan kehidupan ahirat, kepentigan pribad dengan tidak mengenyampingkan kepentingan umum aatau kepentingan social namun memandang pendidikan sebagai satukesatuan untuk mencari kemaslahatan di dunia maupun di ahirat. 


\section{b. Pendidikan}

Manusia adalah mahluk yang mulia dibandingkan dengan mahluk yang lain, kemulyaan manusia terletak pada akal yang senantiasa berkembang. Dalam perkembangannya banyak factor yang mempengaruhinya yakni mampu dikembangkan melalui penciptaan lingkungan yang sesuai dengan tujuan pendidikan. Pendidikan adalah usaha sadar yang dilakukan oleh orang yang lebih dewasa kepada yang lebih muda agar menjadi manusia yang dewasa. Disamping itu menurut Pendidikan adalah proses interaksi antara pendidik dan anak didik dan atau lingkungan secara sadar, teratur, terencana dan sistematis guna membantu pengembangan potensi anak didik secara maksimal. ${ }^{2}$

Berdasarkan pendapat di atas dapat penulis simpulkan bahwa yang dimasud dengan pendidikan adalalah usaha sadar yang dilakukan oleh guru guna membentuk potensi anak didik menjadi manusia yang lebih baik.

Mengingat betapa penting kedudukan pendidikan dalam menopang kelangsungan hidup manusia, maka pendidikan tidak hanya berlangsung di sekolah saja, namun pendidikan juga berlangsung di rumah dan masyarakat bahkan kehidupan ini merupakan pendidikan. Hal ini sependapat dengan ungkapan long life education (pendidikan seumur hidup) ini mengungkapkan bahwa pendidikan tidak hanya sebatas, TK, SD, SMP SMA, SI, S2, dan S3 saja namun pendidikan dimulai sejak dini sampai ke liang lahat. Hal ini dipertegas lagi dengan hadis Nabi sebagai berikut:

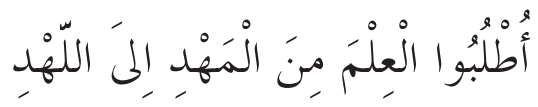

2 Suyadi, Manajemen PAUD. (Yogyakarta: Pustaka Pelajar, 2011), hal. 68. 
"Tuntutlah ilmu sejak dari buaian sampai liang lahat" Hadits tersebut menjadi dasar dari ungkapan "Long life education" atau pendidikan seumur hidup. Kehidupan didunia ini rupanya tidak sepi dari kegiatan belajar, sejak mulai lahir sampai hidup ini berakhir.

Berdasarkan hadis di atas diketahui bahwa pendidikan dimulai sejak usia dilahirkan itu artinya sejak anak dilahirkan anak sudah bisa menerima pendidikan. Pendidikan untuk usia ini tentu saja tidak sama seperti pada anak usia 3-6 tahun ke atas namun pada usia 0 anak hanya diberikan rangsangan dengan memberikan rangsangan akan pendengaran, penglihatan dan indra perabanya. Pada indra pendengaran usia 0 sudah bisa diberikan pendidikan yakni pengasuh bisa memberikan rangsangan dengan memberikan lagu-lagu atau bacaan-abacan al-qur'an karena bacaan-bacaan al-qur'an yang dibacaan kepada anak usia 0 memiliki dampak yang positif terhadap perkembangan otak disamping itu akan membentuk karakter anak didik yang cerdas baik emosiaonalnya maupun kecerdasan daya pikirnya.

\section{c. Pengertian Paud}

Pendidikan anak usia dini (PAUD) adalah jenjang pendidikan sebelum jenjang pendidikan dasar yang merupakan suatu upaya pembinaan yang ditujukan bagi anak sejak lahir sampai dengan usia enam tahun yang dilakukan melalui pemberian rangsangan pendidikan untuk membantu pertumbuhan dan perkembangan jasmani dan rohani agar anak memiliki kesiapan dalam memasuki pendidikan lebih lanjut, yang diselenggarakan pada jalur formal, nonformal, dan informal.

3 http://egauninus.blogspot.com/2013/09/menuntut-ilmu-sekalipun-sampai-ke. html 
Masa anak usia dini merupakan masa emas tumbuh dan kembang baik secara fisik maupun ruhani. Situasi lingkungan yang mendukung dan bersahhabat akan membantu anak untuk mengoptimalkan kemampuannya dalam berfikir dan berkembang karena itu perlu dukungan baik itu segi makanan yang bergizi dan ppenciptaan lingkungan yang mampu mengarahkan emosional anak didik menuju kedalam kebaikan.

Sesuai dengan fitrahnya, bahwa manuisa secara fitrah mengakui dan menimani Allah SWT namun orang tuanyalah yang kemudian membentuknya menjadii yahud atau nasrani. Dengan demikian diketahui bahwa dalam pendidikan orang tua menjadi peran utama dalam membantuk karakter anak didik. Disamping sekolah juga merupakan factor yang tidak kalah penting dalam pembentukan karakter anak bangsa yang beriman, bertaqwa, cerdas dan berketerampilan.

Untuk membentuk anak didik yang sesuai dengan tujuan pendidikan secara nasional tentu tidaklah semudah membalikkan telapak tangan, perlu pemikiran, perencananan, serta penerapan dari perencaanna itu sendiri hingga evaluasi dan tindak lanjut. Hal ini tentu saja dibutuhkan guna pecapaia tujuan pendidikan. Salah satu hal penting yang pelu drencanakan adalah kurikulum. Kurikulum merupakan salah satu elemen yang sangat vital dalam pendidikan. Mengingat kurkulum adalah motor untuk penggerak pendidikan.

\section{d. Pengertian Kurikulum PAUD}

Istilah kurikulum (curriculum) berasal dari kata curir (pelari) dan curere (tempat berpacu). pada awalnya istilah ini digunakan dalam dunia olah raga yang diartikan sebagai jarak yang harus 
ditempuh oleh seorang pelari mulai dari start sampai finish untuk memperoleh medali atau penghargaan. Kemudian pengertian tersebut diterapkan dalam dunia pendidikan menjadi sejumlah mata pelajaran (subject) yang harus ditempuh oleh seorang siswa dari awal sampai akhir program pelajaran untuk memperoleh penghargaan dalam bentuk ijazah. ${ }^{4}$

Pengertian kurikulum sebagaimana disebutkan di atas dinilai terlalu sempit atau sangat sederhana karena ruang lingkup kurikulum terbatas pada kegiatan belajar dan mengajar di kelas. Pengertian kurikulum di atas dimaknai sebagai pengertian kurikulum tradisional. pengertian kurikulum tersebut dinilai tidak sesuai lagi dengan kondisi yang ada pada saat ini, sehingga menuntut para pakar kurikulum untuk memberikan pengertian kurikulum modern. Menurut Harold B. Alberty sebagaimana dikutip oleh Lias hasibuan "“All of the activitiest that are provided for students by the school..." (semua aktivitas yang disediakan untuk siswa oleh sekolah...)" ${ }^{5} \mathrm{Hal}$ ini senada sebagaimana diungkapkan oleh Oemar Hamalik bahwa kurikulum adalah "program pendidikan yang disediakan oleh lembaga pendidikan (sekolah) bagi siswa." ${ }^{\circ}$ Sementara itu menurut Nana Sudjana. Kurikulum adalah "niat dan harapan yang dituangkan dalam bentuk rencana atau program pendidikan untuk dilaksanakan oleh guru di sekolah." Adapun menurut Undang-Undang Nomor 20 Tahun

\footnotetext{
${ }^{4}$ Asep Herry Hernawan et al., Kurikulum dan Pembelajaran (Jakarta: Rajagrafindo Persada, 2011), hal. 2.

5 Lias Hasibuan, Kurikulum dan Pemikiran Pendidikan (Jakarta: Gaung Persada Press, 2010), hal. 7.

6 Oemar Hamalik, Manajemen Pengembangan Kurikulum (Bandung: Remaja Rosdakarya, 2008), hal. 10.

7 Nana Sudjana, Pembina dan Pengembangan Kurikulum di Sekolah (Bandung: sinar Baru Algesindo, 2005), hal. 3.
} 
2003 tentang Sistem Pendidikan Nasional pada bab I, tentang ketentuan umum pasal 1 ayat I dinyatakan bahwa:

Kurikulum adalah seperangkat dan pengaturan mengenai tujuan, isi, dan bahan pelajaran serta cara yang digunakan sebagai pedoman penyelenggaraan kegiatan pembelajaran untuk mencapai tujuan pendidikan tertentu. ${ }^{8}$

Berdasarkan pengertian di atas dapat penulis simpulkan bahwa kurikulum adalah sebuah niat atau pengharapan pendidikan yang terukur dan terencana untuk mencapai suatu tujuan pendidikan yang diwujudkan dalam pelaksaaan pendidikan baik di dalam kelas, maupun di luar kelas. Kurikulum tidak terbatas pada sejumlah mata pelajaran saja dan tidak pula terbatas pada empat dinding saja akan tetapi segala sesutu yang berkaitan dengan sekolah baik itu di dalam sekolah maupun di luar sekolah yakni lingkungan keluarga dan masyarakat, pada saat jam pelajaran berlangsung maupun di luar jam pelajaran.

"Kurikulum merupakan rencana tertulis yang berisi tentang ide-ide dan gagasan-gagasan yang dirumuskan oleh pengembang kurikulum." menurut Nasution sebagiman dikutip oleh Muhaimin bahwa kurikulum adalah sejumlah mata pelajaran atau kuliah di sekolah atau perguruan tinggi, yang harus ditempuh untuk mencpi suatu ijazah atau tingkat. ${ }^{10}$ Sementara Muhamin juga mengutip dari al-Syaibani yang menyebutkan bahwa kurikulum adalah terbatas pada pengetahuan-pengetahuan yang dikemukakan oleh guru atau sekolah atau institusi pendidikan lainnya dalam bentuk mata pelajaran - mata pelajaran atau kitab-

${ }^{8}$ Departemen Pendidikan Nasional, Kurikulum Berbasis Kompetensi (Jakarta: Balitbang Depdiknas, 2002), hal. 1.

9 Wina Sanjaya, Kurikulum dan Pembelajaran" (Jakarta: Kencana 2008), hal. 16.

${ }^{10}$ Muhaimin, Pengembangan Kurikulum Pendidikan Agama Islam"(Jakarta: Raja Grafindo Persada 2005), hal. 2. 
kitab karya ulama terdahulu, yang dikaji begitu lama oleh para pendidikanya peserta didik dalam tiap tahap pendidikannya ${ }^{11}$

Berdasarkan beberapa pendapat di atas dapat disimpulkan bahwa kurikulum merupakan sebuah rencana yang memuat hal-hal yang berkaitan dengan pelaksanaan kegiatan belajar dan mengajar mulai dari tujuan, materi tau isi, metode, media dan alat evaluasi.

Sementra itu Kurikulum PAUD adalah sebuah kurikulu yang di desain untuk memberikan kesiapan kepada anak didik untuk melanjutkan jenjang pendidikan yang lebih tinggi yakni Taman Kanak-Kanak (TK) atau Raudhotul Athfal (RA). Kurikulum merupakan sebuah alat guna mencapai sebuh tujuan pendidikan yang di inginkan sesuai dengan visi dan misi sekolah yang mendukung visi misi pendidikan Nasional. Berdasarkn visi dan misi tersebut sebuah kurikulum di susun dan kemudian di implementasikan. Hal ini sesui dengan hadis nabi bahwa

Berdasarkan ayat ini sangat jelas bahwa sebuah kurikulum memiliki peranan penting dalam pembentukan pengetahuan, keterampilan maupun ahlaq anak didik. Kurikulum berbasis al-quran (KBQ) merupakan kurikulum yang tidak memisahkan pengetahuan agama dengan pengetahuan umum namun KBQ merupakan sebuah kurikulum yang memadukan antara mata pelajaran umum dengan mata pelajaran agama dimana keduanya merupakan satu kesatuan yang tidak dapat dipisahkan; yang tidak hanya memberikan keungguln kognitif, ketarampilan,afektif namun keyakinan yang kokoh akan agama serta penanaman ahlaq sejak dini kepada nk-anak perlu ditanamkan sedini mungkin.

${ }^{11}$ Ibid. 
KBQ memiliki ciri-ciri umum, sebagai berikut: a. Agama dan akhlak merupakan tujuan utama. Segala yang diajarkan dan di amalkan harus berdasarkan pada Al-Qur'an dan As-Sunnah serta ijtihad para ulama. b. Mempertahankan pengembangan dan bimbingan terhadap semua aspek pribadi siswa dari segi intelektual, psikologi, sosial, dan spiritual. c. Adanya keseimbangan antara kandungan kurikulum dan pengalaman serta kegiatan pengajaran.

Di samping itu, kurikulum pendidikan Islam juga memiliki ciri-ciri khusus, di antaranya:

1. Dalam kurikulum pendidikan Islam, tujuan utamanya adalah pembinaan anak didik untuk bertauhid. Oleh karena itu, semua sumber yang dirunut berasal dari ajaran Islam.

2. Kurikulum hrus disesuaikan dengan fitrah manusia, sebagai makhluk yang memiliki keyakinan kepada Tuhan.

3. Kurikulum yang disajikan merupakan hasil pengujian materi dengan landasan Al-Qur'an dan As-Sunnah.

4. Mengarahkan minat dan bakat serta meningkatkan kemampuan akliah anak didik serta keterampilan yang akan diterapkan dalam kehidupan konkret.

5. Pembinaan akhlak anak didik, sehingga pergaulannya tidak keluar dari tuntunan Islam, dan

6. Tidak ada kadaluarsa kurikulum karena ciri khas kurikulum Islam senantiasa relevan dengan perkembangan zaman bahkan menjadi filter kemajuan ilmu pengetahuan dan teknologi dalam penerapannya di dalam kehidupan masyarakat. 
Oleh karena itu dapat dikatakan, bahwa sebagai inti dari ciriciri kurikulum pendidikan Islam adalah kurikulum yang dapat memotivasi siswa untuk berakhlak atau berbudi pekerti luhur, baik terhadap Tuhan, terhadap diri dan lingkungan sekitarnya.

\section{e. Komponen Isi (Materi) Kurikulum Berbasis Al-Qur'an}

Komponen isi kurikulum merupakan komponen penting untuk mencapai tujuan pendidikan. Komponen isi atau materi atau disebut juga dengan mata pelajaran. Di dalam Al-quran Terdapat beberapa petunjuk yang menjelaskan tentang mata pelajaran yang wajib untuk dipelajari sejak dini. Berikut ini beberapa ilmu yang perlu diperkenalkan pada nak sejak dini :

\section{Tauhid}

Tauhid merupakan ilmu yang harus diperkenalkan sejak dini. Ilmu yang memperkenalkan si kecil akan penciptanya, yang menciptakan alam semesta memperkenalkan kepada si kecil bahwa ada kekuatan yang maha besar yang tidak bisa tertandingi oleh mahluk lain selain Allah, memperkenlkan bahwa alam semesta adalah Allah yang menciptakan dan lain sebagainya. Penanaman iman sejjak dini sangat penting hal ini sebagaimana metode dakwah nabi hal yang pertaman kali disampaikan adalah keyakinan kepada Allah SWT bukan bagaimana bermain music, bela diri, dan lain-lain yang sifatnya keduniaan. Berikut ini ayat yang berkenaan tentang wajibnya mempelajari ilmu tauhid sejak dini kepada anak.

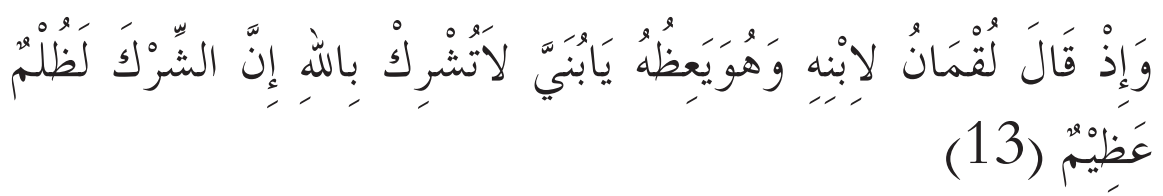




\section{Artinya:}

Dan (ingatlah) ketika Lukman berkata kepada anaknya, di waktu ia memberi pelajaran kepadanya: "Hai anakku, janganla $h$ kamu mempersekutukan (Allah) sesungguhnya mempersekutukan (Allah) adalah benar-benar kelaliman yang besar". (Q.S Luqman : 13)

Dalam ayat ini Allah mengabadikan kisah Lukman yang mengajarkan Tauhidkepadaananknya. Dariayatinihendaknyabisa menjadi pedoman bagi orang tua murid untuk memperkenalkan Allah sejak dini terlebih pada lembaga pendidikan yang berbasis Islam.

Pengenalan Ilmu tauhid kepada anak usia dini tentu tidak sama sebagaimana pemberian materi ilmu tauhid kepada anak tingkat SD, SLTP maupun SLTA. Pengenalan ilmu tauhid kepada anak didik tingkat PAUD tentu saja dengan pemilihan metode dan strategi yang tepat untuk anak didik tingkat PAUD dengan di dukung media yang tepat, menyenangkan dan bervariasi. Sehinggat tujuan pembelajaran tercapai namun anak-anak tetap seperti merasa bermain. Karena memang dunia anak PAUD adalah bermain namun guru PAUD dituntut untuk mampu memasukkan edukasi dalam tiap-tiap permainannya diantaranya Ilmu tetang Tauhid.

\section{Al-Qur'an atau Iqra' (Membaca)}

Al-Qur'an merupakan kalamuAllah yang diturunkan melalui malaikat Jibril kepada Nabi Muhammad SAW. Didalamnya terdapat pedoman hidup manusia dalam menjalani kehidupan dunia dan keselamatan hirat, peringatan sekaligus janji surga bagi orang-orang yang beriman dan beramal shlih. Mengingat begitu penting kedudukan al-Quran bagi kehidupan orang-orang 
muslim maka menjadi wajib hukumnya bagi orang-orang Islam untuk mempelajari Al-Qur'an.. Hadis yang berkenaan dengan pentingnya pengenalan ilmu al-Qur'an sejak dini adalah sebagai berikut:

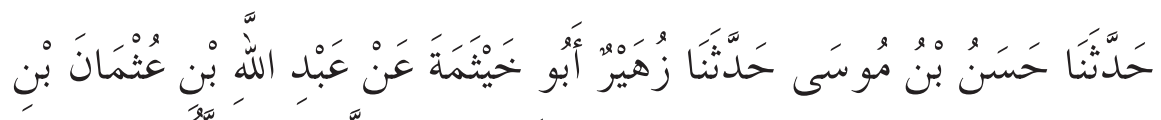

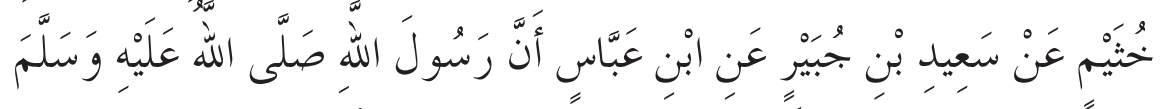

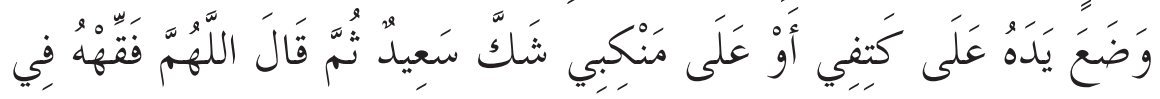

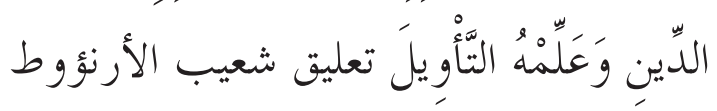

Artinya: "Dari Ibnu 'Abbas bahwasanya Rasulullah SAW meletakkan tanggannya pada punggung Ibnu 'Abbas atau pundaknya, - perawi Hadis ini, Said ragu-kemudian Rasulullah SAW berdo'a: Ya Allah berikanlah kepadanya pemahaman yang mendalam tentang agama dan ajarilah dia takwil (al-Qur'an). (Ahmad ibn Hanbal Abu Abdullah al-Syiyabaani, tt: 266).

Rasulullah SAW telah bersabda:

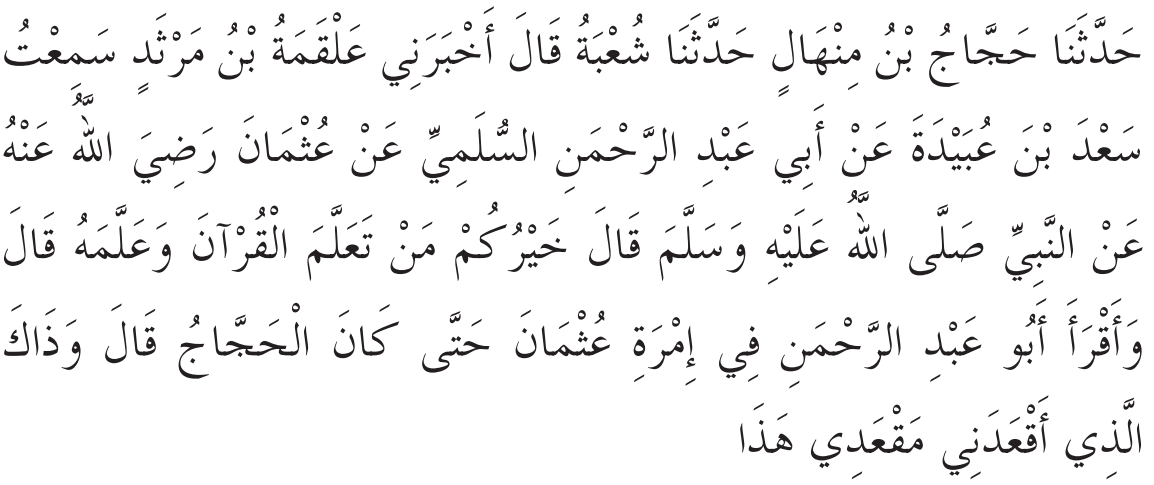

Artinya:"Telah menceritakan kepada kami hujjaj ibn Minhaal telah menceritakan syu'bah ia berkata 'Alqamah ibn mursyid telah mengkhabarkan kepadaku saya mendengar Said ibn 'Ubaidah dari ayah 
Abdurrahman al-silmy dari 'Usman ra Nabi SAW telah bersabda: "Yang paling baik di antara kamu adalah orang yang mempelajari Al-Quran dan mengajarkannya."(HR. Bukhari,1987:1919)

Membaca merupakan materi pertama yang diberikan kepada Anak mengingat membaca merupakan kunci pertama untuk mempelajari ilmu-ilmu selanjutnya. Selain itu membaca merupakan kunci untuk bisa mengucpkan bacaan-bacaan yang ada di dalam ibadah Sholat. Karena itula pengenalan huruf hijaiyyah kepada Anak PAUD menjadi sangat mutlak untuk diberikan.

\section{Akhlak (Budi Pekerti)}

Mata pelajaran akhlak atau budi pekerti merupakan mata pelajaran yang tidak kalah penting dengan mata pelajaran Ilmu Tauhid dasar dan membaca Al-Qur'an dasar. Mata pelajaran Akhlak dalah mata pelajaran yang memperkenalkan kepada anak didik untuk memilih sikap-sikap yang terbaik untuk di amalkan dalam kehidupan sehari-hari. Hal ini sangat jelas Allah perintahkan sebagaimana Allah menjelaskan dalam al-Qur'an sebagai berikut:

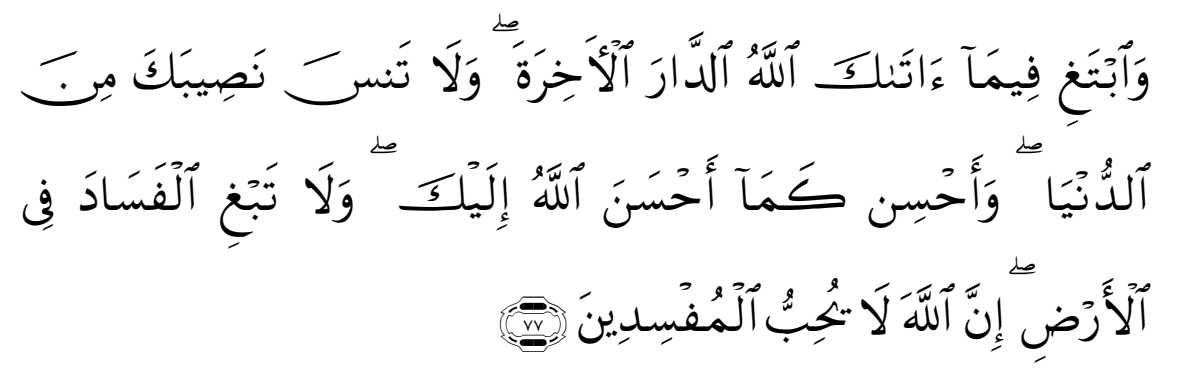

Artinya: Dan carilah pada apa yang telah dianugerahkan Allah kepadamu (kebahagiaan) negeri akhirat, dan janganlah kamu melupakan bahagianmu dari (kenikmatan) duniawi dan berbuat baiklah 
Vol. III, No. 1, April 2015

(kepada orang lain) sebagaimana Allah telah berbuat baik kepadamu, dan janganlah kamu berbuat kerusakan di (muka) bumi. Sesungguhnya Allah tidak menyukai orang-orang yang berbuat kerusakan. (QS: AlQashash : 77)

\section{Pendidikan Jasmani}

Pada masa Madinah, Nabi SAW telah memasukkan materi kesehatan dan kekuatan jasmani dalam kurikulum pendidikannya. Secara praktis (amaliah) shalat, wudhu', mandi, puasa dan haji telah mengandung pendidikan kesehatan dan kekuatan fisik. Selain itu Nabi juga mengajarkan agar makan dan minum secara sederhana, tidak berlebihan. Nabi pun mengajak mempelajari cara berperang. Tentu saja tujuan utamanya untuk persiapan pembelaan diri. Beliau bersabda:
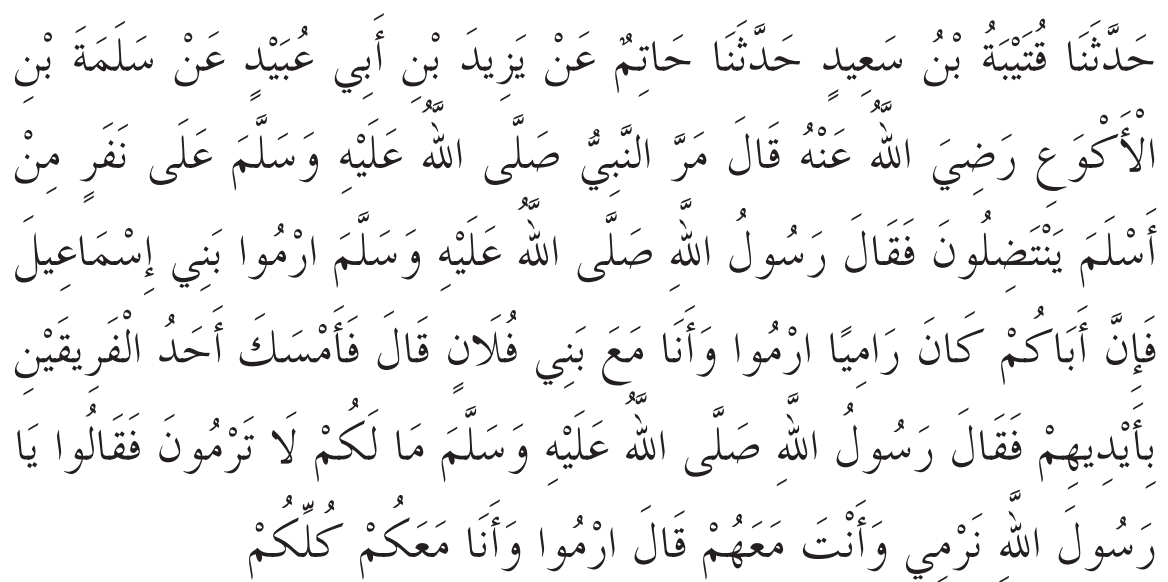

Artinya: Telah menceritakan kepada kami Qutaybah ibn Sa'id, telah bercerita Hatim dari yazid bin Abi 'Ubaid dari salamah, telah menceritakan kepada kami samah ra berkata: Pada suatu hari Rasulullah SAW bersua dengan sekelompok orang dari Bani Aslam yang sedang berlomba memanah, maka beliau SAW bersabda: Memanahlah kalian, hai bani Ismail, sebab nenek moyangmu dahulu (Ibrahim As) adalah 
seorang pemanah.Panahlah dan saya bersama bani fulan. Maka salah satu kelompok berhenti. Rasul bersabda: kenapa kamu tidak memanah, maka mereka berkata: wahai Rasulullah SAW kami memamah tapi kamu memihak kepada mereka, Rasul pun bersabda: Panahlah dan saya bersama kalian semuanya. (HR. Bukhari, 1987: Kitab Jihad No. 2684)

Berikut juga sebuah anjuran untuk memanfaatkan waktu luang anak dalam bentuk kegiatan yang berguna. Anak sebaiknya dianjurkan pula untuk melakukan perlombaan olah raga lainnya, seperti berlari, menunggang kuda dan berenang. Semua itu dapat menumbuhkan keberanian dan kehandalan dalam jiwa anak-anak sekaligus menghilangkan sifat pengecut. Oleh sebab itu Islam mengajak untuk memiliki kekuatan yang halal dan menganggap orang mukmin yang kuat jasmani, rohani atau akal dan semangatnya, lebih dicintai Allah SWT dan lebih mulia dari pada orang mukmin yang lemah. Juga Islam mengajak untuk membela diri dan kehormatan dan mengajak untuk menghadapi musuh dan menghalanginya jika mereka mulai mengancam.

5. Bahasa, Filsafat, Astronomi, Matematika Dan Kedokteran

Bahasa merupakan alat komunikasi, pembelajaran bahasa untuk tingkat PAUD bukan berarti mempelajari grammer, namun lebih kepada pengenalan kosa kata. Pembelajaran bahasa sejak dini akan memperkaya anak tentang kosa kata mengingat anak usia PAUD memiliki keingin tauhuan yang sangat besar tentang kosa kata dari tiap-tiap benda yang ada disekitarnya. Adapun metode dan teknik pembelajarannya tentu saja disesuaikan dengan kemampuan anak didik. Berikut ini hadis yang berkaitan tentang pengenalan bahasa pada anak usia dini: 


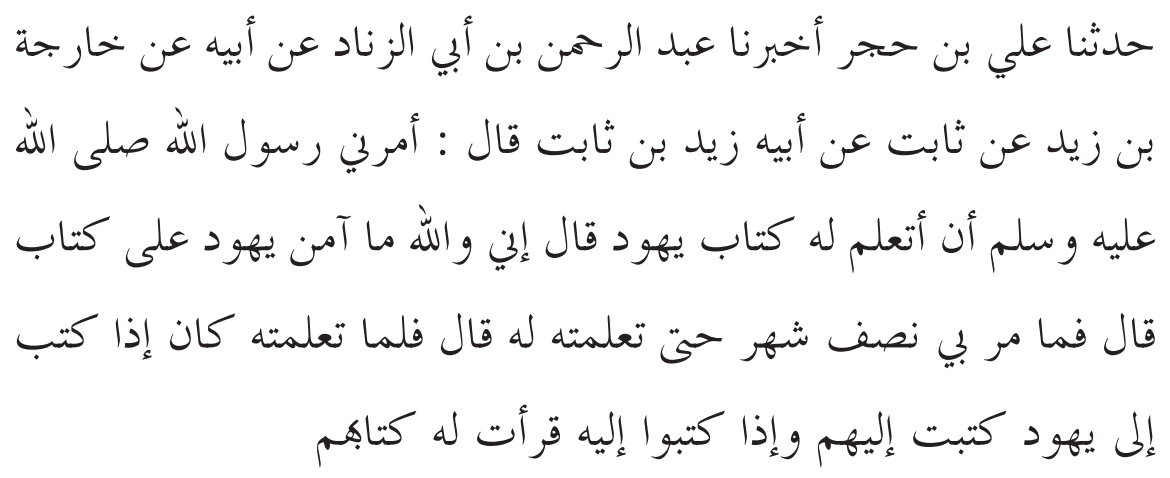

Artinya:"Zayd ibn Tsabit, ia berkata: Rasulullah SAW memerintahkan kepadaku untuk mempelajari bahasa Ibrani guna menterjemahkan surat orang-orang Yahudi. Zaid berkata dengan nada semangat:"Demi Allah, sesungguhnya akan kubuktikan kepada orang-orang Yahudi bahwa aku mampu menguasai bahasa mereka." Zaid melanjutkan: "setengah bulan berikutnya aku mempelajarinya untuk Nabi SAW dengan tekun dan setelah aku menguasainya, maka aku menjadi juru tulis Nabi SAW apabila beliau berkirim surat kepada mereka, akulah yang menuliskannya; dan apabila beliau menerima surat dari mereka, akulah yang membacakan dan yang menerjemahkannya untuk Nabi SAW."

\section{f. Metode Pembelajaran Pada Anak Usia Dini (PAUD)}

Untuk mengajarkan mata pelajaran-mata pelajaran kepada anak usia dini (PAUD) tentu tidak sama dengan metode pembelajaran pada anak tingkat SD, SMP apalagi SMA . KBQ adalah sebuah kurikulum yang memberikan pengetahuan yang sempurna karena anak didik tidak hanya dibekali ilmu umum namun diberikan pondasi keimana yang kokoh sehingga di masa depannya menjadi manusia yang tidak hanya berilmu pengetahuan saja namun memiliki krakter yang islami. Dalam implementasinya kurikulum perlu di sampaikan dengan sejumlah metode-metode pembelajaran yang sesuai dengan kondisi anak 
didik. Dibawah ini beberapa metode yang bisa diterapkan dalam kegiatan belajar dan mengajar untuk pendidikan anak usia dini yakni metode bermain, metode bercerita, metode menyanyi atau music, Metode karya wisata, metode demontrasi.

\section{Metode Bermain}

Metode bermain adalah sebuah metode pembelajaran yang menerapkan permainan sebagai wahana pembelajaran siswa. Teknik ini didasarkan penelusuran literature maupun pengamatan sepintas dilapangan terbukti paling efektif dan efisien dibandingkan dengan metode yang lain. Kemampuan belajar mengingat anak menjadi cepat dan banyak serta anak tidak merasa jenuh. Setidaknya ada 5 manfaat nyata dari metode bermain ini diantaranya yaitu manfaat motorik adalah manfaat yang berhubugan dengan nilai-nilai positif mainan yang terjadi pada fisik jasmani anak. Manfaat afeksi adalah manfaat mainan yang berhubungann dengan perkembangan psikologis anak. Manfaat Kognitif adalah manfaat mainan untuk perkembangan kecerdasan anak, biasanya ini berhubungan dengan kamampuan imajinasi pada anak. Manfaat Spiritual adalah manfaat mainan yang menjadi dasar pembentukan nilai-nilai kesucian maupun keluhuran akhlak manusia. Sedangkan manfaat keseimbangan adalah suatu jenis mainan bagi tumbuh kembang anak dimana mainan berfungsi untuk melatih dan mengembangkan perpaduan nilai-nilai positif dan negative dari mainan.

\section{Metode Cerita}

Metode cerita adalah metode pembelajaran yang menggunakan teknik guru bercerita tentang suatu legenda, dongeng, mitos, atau suatu kisah yang didalamnya diselipkan pesan-pesan moral 
atau intelektual tertentu. Hal ini akan berguna bagi anak ketika suatu saat ia menemukan masalah yang hampir mirip dengan kisah atau dongeng yang pernah diceritakan gurunya. Darii kisah itu alam bawah sadar anak akan memicu nalar konstruktif pemecahan masalah yang dihadapi sesuai pesan-pesan moral atau intelektual yang diajarkan.

\section{Metode Menyanyi / Musik}

Metode menyanyi adalah metode pembelajaran yang menggunakan media nyanyian sebagai wahana belajar anak. Menurut Grace Soedargo, seorang musisi dan pendidik "dasardasar music klasik, secara umum berasal dari ritme denyut nadi manusia sehingga ia berperan besar dalam perkembangan otak, pembentukan jiwa, karakter bahakan raga manusia" Penelitian menunjukkan bahwa music klasik yang mengandung komposisi nada berfluktuasi antara nada tinggi dan nada rendahakan merangsang kuadran C pada otak. Sampai usia 4 tahun kuadaran Bdan C pada otak anak-anak akan berkembang hingga 80\% dengan musik.

Menurut Ev. Andreas Christanday, music sangat mempenagruhi kehidupan manusia. Music memiliki 3 bagian penting yaitu "beat" mempengaruhi tubuh, "ritme"mempengaruhi jiwa, dan "harmony" mempengaruhi ruh.

\section{Metode Karyawisata}

Bagi anak karyawisata berarti memperoleh kesempatan untuk memperoleh informasi atau mengkaji sesuatu secara langsung (Hildebrand dalam Moslichatoen, 1999). Karyawisata berarti berarti membawa anak ke objek-objek tertentu sebagai pengayaan pngajaran, pemberian pengalaman belajar yang 
tidak mungkin diperoleh didalam kelas. (Welton \& Malloton dalam Moeslichatoen 1999) dan juga memberi kesempatan anak untuk mengobservasi dan mengalami sendiri dari dekat (Foster \& Headly's, 1959). Berkaryawisata mempunyai makna penting bagi perkembangan anak karena dapat membangkitkan minat anak pada sesuatu hal, memperluas perolehan informasi, juga memperkaya lingkup program kegiatan belajar anak yang tidak mungkin dihadirkan dikelas.

\section{Metode Demonstrasi}

Demonstrasi berarti menunjukkan dan menjelaskan. Jadi dalam demonstrasi kita menunjukkan dan menjelaskan caracara mengerjakan sesuatu. Melalui demonstrasi diharapkan anak dapat mengenal langkah-langkah pelaksanaan. Demonstarsi mempunyai makna penting bagi anak yaitu:

a. Dapat memperlihatkan secara konkret apa yang dilakukan

b. Membantu mengembangkan kemampuan mengamati kemampuan mengamati secara cermat dan teliti.

c. Membantu mengembangkan kemampuan untuk melakukan segala pekerjaan secara teliti, cermat dan tepat.

d. Membantu mengembangkan peniruan dan pengenalan secara tepat.

e. Keterampilan Proses Dasar Pada Jenjang PAUD

\section{a. Pengamatan}

Anak pada proses pengamatan adalah dengan menggunakan fungsi panca indera, anak melihat, mendengar, merasa, membau, serta meraba. Seperti 
contoh guru member arahan anak untuk melihat gambar, mendengar musik, merasakan makanan yang ditugaskan untuk dibawa anak. Dari kegiatan ini anak akan lebih mengerti apa - apa yang ia kerjakan.

\section{b. Mengklasifikasikan}

Setelah anak melakukan kegiatan pengamatan, mendengarkan, dsb. Klegiatan selanjutnya anak adalah mencari perbedaan, yang di maksud dalam tahap ini adalah anak setelah mengamati seperti melihat gambar gajah dengan kucing, maka anak dapat membedakan bagaimana bentukgajah dan bagaimana bentuk kucing sama ataukah berbeda. Setelah itu anak secara otomatis akan membandingkan bagus yang mana, apabila dikaitkan dengan merasa anak akan membandingkan enakan mana masakan ibu sendiri dari rumah dengan masakan yang disediakan di sekolah.

\section{c. Menginterpretasikan}

Dari kegiatan awal anak dituntun untuk pengamatan, membandingkan, maka proses selanjutnya adalah anak member arti, menemukan pola yaitu anak akan mengerti bahwa gajah itu besar memiliki belalai panjang, sedangkan kucing kecil dan memiliki kumis dan lain sebagainya.

\section{d. Meramalkan}

Tahap ini anak diajak untuk bermain menggunakan peramalan yaitu seperti mengajari tentang bagaimana bunyinya gajah, bunyi hewan yang telah dipelajari sebelumnya. 


\section{Kurikulum Berbasis Al-Qur'an (KBQ)... \\ Nur Komariah}

\section{e. Menerapkan}

Setelah proses meramalkan maka anak menerapkan yaitu membuat gambar sebisa mungkin tentang gajah, atau anak mewarnai gambar gajah yang sudah disiapkan oleh guru.

\section{f. Merencanakan}

Guru memberi tugas anak untuk menyebutkan secara nergantian hewan yang ada disekitar rumahnya ataupun benda - benda yang ada disekitar rumahnya apa sakja yang diketahui anak.

\section{g. Mengkomunikasikan}

Tahap terakhir adalah pemberian pembenaran dari guru serta penguatan bahwa gajah itu besar, memiliki belalai, kucing itu kecil, berbulu dan berkumis, serta penanaman sikap moral yang lainnya.

\section{Penutup}

Manusia dilahirkan dalam keadaan Fitrah. Selain dimaknai suci fitrah juga bisa dimaknai sebagai potensi atau condong. Sejak manusia dilahirkan manusia memiliki sejumlah potensi yang kemudian lingkunganlah yang memiliki peran untuk mengembangkannya. Untuk membentuk karakter yang sesui dengan Al-Qur'an dan Hadis maka orangtua memiliki peran penting dalam menggali potensi yang ada pada anak-anaknya melalui pendidikan, baik pendidikan keluarga maupun pendidikan formal. Pendidikan adalah sebuh wadah yang dimaksudkan untuk membina membimbing anak didik agar menjadi manusia yang dewasa yang mampu mengemban 


\section{6 \\ Vol. III, No. 1, April 2015}

tugas sebagi kholifah fi al-ard. KBQ adalah sebuah kurikulum yang memberikan materi-materi pelajaran agama mulai dari pengenalan Allah sebagai Robnya, Al-Qur'an dasar, berhitung dasar, membaca dasar dan lain sebagainya, dalam KBQ mata pelajaran agama dan mata pelajaran umum merupakan mata pelajaran yang tidak bisa dipisahkan satu sama lainnya, namun mata pelajaran yang paling utama untuk diperkenalkan kepada anak didik tingkat PAUD adalah mata pelajaran Agama karena mata pelajaran agama seperti pengenalan akan tuhannya adalah suatu kebutuhan yang sangat penting untuk diperkenalkan sejak dini mengingat kebutuhn hakiki manusia adalah mengenal Allah sebagai Robnya. didalam KBQ guru dituntut untuk mampu mengamalkan ajaran-ajaran yang terkandung di dalam Al-qu'an di dalam kehidupan sehari-hari kemudian mengajarkannya pada anak didik untuk menjadikan al-Qur'an dan al-Hadis sebagai pedoman dalam menjalani kehidupannya. 


\section{Kurikulum Berbasis Al-Qur'an (KBQ)... \\ Nur Komariah}

\section{DAFTAR PUSTAKA}

Achmadi, 2005, Ideologi Pendidikan Islam, Yogyakarta: Pustaka Pelajar.

Asep Herry Hernawan et al., Kurikulum dan Pembelajaran, Jakarta:

Rajagrafindo Persada, 2011.

Departemen Pendidikan Nasional, Kurikulum Berbasis Kompetensi, Jakarta: Balitbang Depdiknas, 2002.

Lias Hasibuan, Kurikulum dan Pemikiran Pendidikan, Jakarta:

Gaung Persada Press, 2010.

Muhaimin, Pengembangan Kurikulum Pendidikan Agama Islam”, Jakarta: Raja Grafindo Persada 2005.

Nana Sudjana, Pembina dan Pengembangan Kurikulum di Sekolah, Bandung: sinar Baru Algesindo, 2005.

Oemar Hamalik, Manajemen Pengembangan Kurikulum, Bandung: Remaja Rosdakarya, 2008.

Suyadi, Manajemen PAUD. Yogyakarta: Pustaka Pelajar, 2011

Wina Sanjaya, Kurikulum dan Pembelajaran”, Jakarta: Kencana 2008.

http://afdhalilahi.blogspot.com/2013/05/kurikulumpendidikan-islam.html

http://juonorp.blogspot.com/2013/10/mendidik-anakmenurut-al-quran-surah.html

https://fathimah1.wordpress.com/2012/12/31/hadis-hadistentang-kurikulum-pendidikan/

http://abufathirabbani.blogspot.com/2012/05/pendidikanakhlakmoral-dalam.html 
98

http://edukasi.kompasiana.com/2014/05/26/metodepembelajaran-paud-659952.html

http://egauninus.blogspot.com/2013/09/menuntut-ilmusekalipun-sampai-ke.html 